\title{
PENGARUH INTENSITAS OLAH RAGATERHADAP KADAR HORMON GNRH (GONADOTROPIN RELEASING HORMON) PADA SIKLUS HAID ALTET DI PUSAT PEMBINAAN LATIHAN PELAJAR MAKASSAR
}

\author{
Sri Wahyuni Gayatri Basri*, Sri Vitayani** A. Multazam ${ }^{* *}$, M. Khidri Alwi** ${ }^{* *}$ Arman**, \\ Nurhaedar Djafar** \\ *Bagian Biokomia Fakultas Kedokteran UMI \\ **Dosen Pascasarjana Universitas Muslim Indonesia
}

\begin{abstract}
Abstrak: Aktivitas fisik yang tinggi dari atlet wanita dapat menyebabkan gangguan menstruasi dari sumbu hipofisis akibat dari perubahan tingkat hormon. Tujuan dari penelitian ini adalah untuk mengetahui Pengaruh intensitas olah raga terhadap kadar hormon GNRH pada siklus haid altet di pusat pembinaan latihan pelajar Makassar. Penelitian ini menggunakan metode penelitian analitik dengan pendekatan cross sectional study. Penelitian dilakukan di Pusat Pembinaan Latihan Pelajar Makassar. Banyaknya sampel sebesar 33 orang atlet wanita yang lebih dari 1 tahun pendidikan dan yang telah mengalami menstruasi. Analisis data yang digunakan antara lain Chi-Square dan Regresi Linier Berganda. Hasil uji statistic (ChiSquare) menunjukkan tidak ada hubungan antara jenis olah raga dengan hormone FSH nilai $\mathrm{p}$ $(0,125)$,namun ada hubungan yang signifikan antara durasi olahraga nilai $\mathrm{p}(0,01)$ dan frekuensi olahraga $\mathrm{p}(0,03)$ dengan kadar hormone FSH. Untuk hormone LH tidak didapatkan hubungan antara jenis olahraga $p(0,51)$, durasi olahraga $p(0,65)$ dan frekuensi olahraga $p(0,36)$. Didapatkan ada hubungan yang signifikan antara jenis olahraga $\mathrm{p}(0,046)$, durasi olahraga $\mathrm{p}$ $(0,002)$ dan frekuensi olahraga $p(0,007)$ dengan siklus haid. Pada hubungan hormone FSH dan LH didapatkan hubungan yang signifikan dengan nilai $p(0,000)$ terhadap siklus haid. Hasil uji statistic dengan Regresi Linier Berganda didapatkan frekuensi olahraga memiliki pengaruh terhadap hormone FSH dengan nilai p (0,001), durasi olahraga memiliki pengaruh terhadap siklus haid dengan nilai $\mathrm{p}(0,001)$ dan hormone FSH memiliki pengaruh terhadap siklus haid dengan nilai $\mathrm{p}(0,00)$. Disimpulkan bahwa ada pengaruh frekuensi olahraga terhadap kadar hormone FSH, ada pengaruh durasi olahraga terhadap siklus haid dan ada pengaruh kadar hormone FSH terhadap siklus haid pada atlet wanita di Pusat Pembinaan Latihan Pelajar.
\end{abstract}

Kata Kunci: Intensitas Olahraga, Hormon GnRh, Siklus Haid Atlet

\section{PENDAHULUAN}

Olahraga dan aktivitas fisik yang moderat memiliki banyak manfaat bagi orang-orang dari segala usia. Hal tersebut jika dilakukan secara rutin dapat meningkatkan kualitas hidup dan mengurangi resiko terkena penyakit kardiovaskular, diabetes tipe 2, kanker payudara, masalah usus besar, gangguan kesehatan tulang. Kurangnya aktifitas fisik juga merupakan penyebab 
utama kebanyakan penyakit kronis. Bahkan 6-10\% dari kematian secara global dikaitkan dengan kurangnya olahraga atau aktivitas fisik (Ainsworth and Macera, 2018). Aktifitas fisik yang kurang telah dikaitkan dengan peningkatan risiko obesitas, diet yang kurang sehat, dan rendahnya kebugaran kardiorespirasi bagi seluruh kalangan usia (Duan et al., 2015, Xu and Gao, 2018).

Manfaat penting olahraga tersebar cukup cepat di kalangan masyarakat. Olahraga telah terbukti sangat jitu dalam menjaga kebugaran fisik, upaya menghindari berbagai jenis penyakit, meningkatkan daya tahan tubuh, dan bahkan dijadikan sebagai salah satu alternatif dalam memperoleh atau mempertahankan berat badan ideal. Olahraga yang teratur dan aktif sangatlah besar perannya dalam upaya meningkatkan derajat kesehatan masyarakat. Namun, aktifitas olahraga yang berlebihan juga dapat menimbulkan masalah kesehatan lainnya. Olahraga yang berlebihan akan menunjukkan dampaknya pada efek fisik terlebih dahulu. Kelebihan olahraga atau overtraining dapat menyebabkan peningkatan denyut jantung saat istirahat. Jika detak jantung istirahat meningkat lebih dari lima denyut per menit, maka besar kemungkinan akan mengarah pada terjadinya sindromovertraining (Kreher and Schwartz, 2012).

Olahraga dengan dosis sangat tinggi dapat dikaitkan dengan peningkatan risiko fibrilasi atrium, penyakit arteri koroner, dan aritmia ventrikel yang ganas. Kelebihan olahraga juga dapat menyebabkan dilatasi jantung, disfungsi jantung, dan pelepasan troponin dan peptida natriuretik otak. Olahraga yang berlebihan ini biasanya dialami oleh para atlet. (Lavie et al., 2015).
Atlet merupakan seseorang yang mahir dalam olahraga dan bentuk lain dari latihan fisik, terutama yang mengikuti perlombaan atau pertandingan (kekuatan, ketangkasan, dan kecepatan). Maksud dari program latihan olahraga untuk atlet adalah untuk meningkatkan kapasitas kinerja fisik mereka. Dalam upaya untuk meningkatkan kinerja fisik dan menyebabkan adaptasi fisiologis yang positif, atlet yang kompetitif harus melakukan sejumlah besar latihan secara teratur. Jika tekanan pelatihan rejimen berlebihan (melibatkan terlalu banyak intensitas, dan / atau mengandung volume pekerjaan yang terlalu besar), atau atlet memiliki terlalu banyak tekanan hidup tambahan selama pelatihan, mungkin terjadi malformasi fisiologis (Hackney and Koltun, 2012).

Pada atlet wanita, aktifitas fisik dalam bentuk olahraga yang berlebihan dapat mempengaruhi siklus menstruasinya. Aktivitas intensitas tinggi dikaitkan dengan disfungsi menstruasi dan subfertilitas di antara atlet wanita berperforma tinggi. Aktivitasberintensitastinggidikaitkan dengan amenorrhea, oligomenorrhea, defisiensi fase luteal, dan anovulasi, kemungkinan melalui gangguan dari aksis hipotalamus-hipofisis (Ahrens et al., 2014). Penekanan hormon gonadotropine (GNRH) yang dihasilkan dari disfungsi hipotalamus terkait olahraga dapat menunda menarche dan mengganggu pola siklus menstruasi dengan membatasi sekresi luteinizing hormone (LH) dan folliclestimulating hormone (FSH) (Ahrens et al., 2014).

Siklus menstruasi yang teratur merupakan indikator penting dari sistem reproduksi yang sehat. Faktor obesitas, 
stres, dan merokok merupakan faktor yang berhubungan dengan menstruasi tidak teratur dan menopause dini. Pada tahun 2014, jumlah wanita yang mengalami kesulitan untuk hamil meningkat sebesar 160.000 yakni sekitar $65 \%$ selama dekade terakhir. Selain itu, studi tentang hubungan yang mungkin antara paparan berbagai penyakit dan siklus menstruasi yang tidak teratur atau gejala menopause dini pada wanita menopause telah dilakukan (Rahman etal., 2015, Bae et al., 2018).

Berbagai hormon mempengaruhi siklus menstruasi. Siklus menstruasi yang tidak teratur adalah gejala utama dari anovulasi, sebuah fenomena yang disertai dengan penurunan sekresi steroid ovarium dan produksi (Van Voorhis et al., 2008, Mumford et al., 2012). Penyebab paling penting dari ketidakteraturan siklus menstruasi adalah amenorrhea hipotalamus fungsional terkait dengan penurunan sekresi hormon gonadotropin-releasing (GNRH) dan disregulasi aksis hipotalamus-hipofisisadrenal (HPA). Sambungan hipotalamus yang mengatur pola dan amplitudo pulsa $\mathrm{GnRH}$ adalah plastik dan merespon kondisi eksternal / psikologis dan faktor internal / metabolik yang dapat mempengaruhi substrat hipotalamus di mana tingkat estrogen dapat bertindak (Berga and Naftolin, 2012).

Kekurangan gonadotropin juga cukup menghambat hormon penstimulasi Lutein (LH) dan Follicle (FSH) dan ini menyebabkan pelepasan estradiol dan progesteron yang tidak mencukupi (Aviz et al., 2014). Oleh karena itu, situasi yang penuh tekanan seperti olahraga intens akan mengganggu sistem reproduksi wanita melalui poros hipofisis. Faktor utama penyebab supresi
GnRH atlet wanita adalah penggunaan energy yang berlebihan yang melebihi pemasukan energi pada atlet. Faktor kekurangan nutrisi merupakan faktor penting penyebab keadaan hipoestrogen pada atlet wanita (Salehzadeh, 2015).

Di Indonesia, telah dilaporkan pula hubungan aktivitas fisik dengan terjadinya gangguan siklus menstrusi. Seperti penelitian yang dilakukan oleh Yani (2016) yang melaporkan bahwa sebagian besar akitivitas fisik atlet berada pada kategori berat, yaitu sebanyak 39 orang $(88,6 \%)$ dan siklus menstruasi atlet sebagian besar mengalami oligomenorrhea sebanyak 26 orang (27,3\%), dan adanya hubungan antara aktivitas fisik dengan siklus menstruasi pada atlet. Selain itu, Mahitala (2015) juga melaporkan ada hubungan aktivitas fisik dengan gangguan menstruasi wanita Pasangan Usia Subur $(p=0,008<0,05)$. Pada penelitian yang melibatkan atlet basket wanita, dilaporkan bahwa sebagian besar atlet basket mengalami polimenorea, beberapa mengalami oligomenorea, dan hanya 1 atlet yang pernah mengalami amenorea sekunder (Tanudjaja et al., 2016). Hasil penelitian serupa juga dilaporkan oleh Kurniawan et al. (2016) menunjukkan bahwa terdapat hubungan yang bermakna antara frekuensi dan lama latihan dengan siklus menstruasi. Sementara penelitian terkait aktifitas fisik dengan hormon GnRH pada siklus menstruasi atlet masih minim dilakukan.

Berdasarkan latar belakang tersebut maka penelitian ini dilakukan untuk mengetahui pengaruh intensitas olah raga terhadap kadar hormon GnRH pada siklus menstruasi atlet di pusat pembinaan latihan pelajar Makassar. 


\section{METODOLOGI}

Penelitian ini menggunakan metode penelitian analitik dengan pendekatan cross sectional study. Penelitian dilakukan di Pusat Pembinaan Latihan Pelajar Makassar. Banyaknya sampel sebesar 33 orang atlet wanita yang lebih dari 1 tahun pendidikan dan yang telah mengalami menstruasi. Analisis data yang digunakan antara lain Chi-Square dan Regresi Linier Berganda.

\section{HASIL PENELITIAN}

Penelitian ini dilakukan di Pusat Pendidikan Dan Latihan Olahraga Pelajar (PPLP) Sulawesi Selatan yang berlangsung mulai bulan Juli - September untuk mengetahui pengaruh intensitas olahraga (jenis, frekuensi, dan durasi olahraga) terhadap kadar $\mathrm{GnRH}$ pada siklus menstruasi atlet wanita.

Tabel1. Jenis Olahragayang digelutioleh atletdiPusatPembinaan Latihan Pelajar Makassar

\begin{tabular}{lcl}
\hline Jenis Olahraga & (n) & (\%) \\
\hline \hline Sedang & & \\
Senam & 5 & 15,2 \\
Atletik & 6 & 18,2 \\
\hline Berat & & \\
Karate & 6 & 18,2 \\
Tinju & 7 & 21,2 \\
Pencak Silat & 5 & 15,2 \\
Taekwondo & 4 & 12,1 \\
\hline Total & $\mathbf{3 3}$ & $\mathbf{1 0 0}$ \\
\hline
\end{tabular}

Sumber: Data primer 2018

Tabel 2.DurasiOlahragayang digeluti olehatletdiPusatPembinaan LatihanPelajar Makassar

\begin{tabular}{ccc}
\hline $\begin{array}{c}\text { Durasi Olahraga } \\
\text { (menit) }\end{array}$ & (n) & (\%) \\
\hline Sedang & 15 & 45,5 \\
Berat & 18 & 54,5 \\
\hline Total & $\mathbf{3 3}$ & $\mathbf{1 0 0}$ \\
\hline
\end{tabular}

Sumber: Data primer 2018

Tabel 3. Frekuensi Olahraga yang digeluti oleh atlet di Pusat Pembinaan Latihan Pelajar Makassar

\begin{tabular}{ccc}
\hline Frekuensi Olahraga & (n) & (\%) \\
\hline Rutin & 5 & 15,2 \\
Sangat Rutin & 28 & 84,8 \\
\hline Total & $\mathbf{3 3}$ & $\mathbf{1 0 0}$ \\
\hline
\end{tabular}

Sumber: Data primer 2018

Tabel 4. Kadar FSH (Folikel Stimulating Hormon) atlet di Pusat Pembinaan Latihan Pelajar Makassar

\begin{tabular}{ccc}
\hline Kadar FSH & (n) & (\%) \\
\hline Rendah & 21 & 63,6 \\
Normal & 12 & 36,4 \\
\hline Total & $\mathbf{3 3}$ & $\mathbf{1 0 0}$ \\
\hline
\end{tabular}

Sumber: Data primer 2018 
Tabel 5. KadarLH (Luteinezing Hormon) atlet di PusatPembinaan Latihan Pelajar Makassar

\begin{tabular}{ccc}
\hline Kadar FSH & (n) & (\%) \\
\hline Rendah & 19 & 57,6 \\
Normal & 14 & 42,4 \\
\hline Total & $\mathbf{3 3}$ & $\mathbf{1 0 0}$ \\
\hline
\end{tabular}

Sumber: Data primer 2018

Tabel 6. Pola Siklus Menstruasi yang Dialami oleh atlet di Pusat Pembinaan Latihan Pelajar Makassar

\begin{tabular}{ccc}
\hline Siklus Menstruasi & (n) & (\%) \\
\hline Polimenorrea & 14 & 42,4 \\
Oligomenorrea & 12 & 36,4 \\
Amenorea & 7 & 21,2 \\
\hline Total & $\mathbf{3 3}$ & $\mathbf{1 0 0}$ \\
\hline
\end{tabular}

Sumber: Data primer 2018

Tabel 7. Analisis pengaruh jenis olahraga terhadap kadar hormone FSH

\begin{tabular}{cccccccc}
\hline \hline \multirow{3}{*}{ Jenis Olahraga } & \multicolumn{9}{c}{ Kadar Hormon FSH } & \multirow{2}{*}{ P } \\
\cline { 2 - 6 } & \multicolumn{2}{c}{ Normal } & \multicolumn{2}{c}{ Rendah } & \multicolumn{2}{c}{ Total } & \\
\cline { 2 - 7 } & $\mathbf{n}$ & $\mathbf{\%}$ & $\mathbf{n}$ & $\mathbf{\%}$ & $\mathbf{n}$ & $\mathbf{\%}$ & \\
\hline Sedang & 6 & 54,5 & 5 & 45,5 & 11 & 100 & \multirow{2}{*}{0,125} \\
Berat & 6 & 27,3 & 16 & 72,7 & 22 & 100 & \\
\hline Total & $\mathbf{1 2}$ & $\mathbf{3 6 , 4}$ & $\mathbf{2 1}$ & $\mathbf{6 3 , 6}$ & $\mathbf{3 3}$ & $\mathbf{1 0 0}$ & \\
\hline
\end{tabular}

Sumber: Data primer 2018

Tabel 8. Analisis pengaruh durasi olahraga terhadap kadar hormone FSH

\begin{tabular}{cccccccc}
\hline \hline \multirow{2}{*}{$\begin{array}{c}\text { Durasi } \\
\text { Olahraga }\end{array}$} & \multicolumn{9}{c}{ Normal } & \multicolumn{2}{c}{ Rendah } & \multicolumn{2}{c}{ Total } & \multirow{2}{*}{ P } \\
\cline { 2 - 7 } & $\mathbf{n}$ & $\mathbf{\%}$ & $\mathbf{n}$ & $\mathbf{\%}$ & $\mathbf{n}$ & $\mathbf{\%}$ & \\
\hline \hline Sedang & 9 & 60,0 & 6 & 40,0 & 15 & 100 & 0,01 \\
Berat & 3 & 16,7 & 15 & 83,3 & 18 & 100 & \\
\hline Total & $\mathbf{1 2}$ & $\mathbf{3 6 , 4}$ & $\mathbf{2 1}$ & $\mathbf{6 3 , 6}$ & $\mathbf{3 3}$ & $\mathbf{1 0 0}$ & \\
\hline \hline
\end{tabular}

Sumber: Data primer 2018

Tabel 9. Analisis pengaruh frekuensi olahraga terhadap kadar hormone FSH

\begin{tabular}{|c|c|c|c|c|c|c|c|}
\hline \multirow{3}{*}{$\begin{array}{c}\text { Frekuensi } \\
\text { Olahraga }\end{array}$} & \multicolumn{6}{|c|}{ Kadar Hormon FSH } & \multirow{3}{*}{$\mathbf{P}$} \\
\hline & \multicolumn{2}{|c|}{ Normal } & \multicolumn{2}{|c|}{ Rendah } & \multicolumn{2}{|c|}{ Total } & \\
\hline & $\mathbf{n}$ & $\%$ & $\mathbf{n}$ & $\%$ & $\mathbf{n}$ & $\%$ & \\
\hline Rutin & 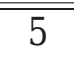 & 100 & 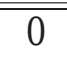 & 0 & 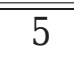 & 100 & \\
\hline Sangat Rutin & 7 & 25,0 & 21 & 75,0 & 28 & 100 & 0,03 \\
\hline Total & 12 & 36,4 & 21 & 63,6 & 33 & 100 & \\
\hline
\end{tabular}

Sumber: Data primer 2018 
Tabel 10. Analisis pengaruh jenis olahraga terhadap kadar hormone LH

\begin{tabular}{|c|c|c|c|c|c|c|c|}
\hline \multirow{3}{*}{ Jenis Olahraga } & \multicolumn{6}{|c|}{ Kadar Hormon FSH } & \multirow{3}{*}{$\mathbf{P}$} \\
\hline & \multicolumn{2}{|c|}{ Normal } & \multicolumn{2}{|c|}{ Rendah } & \multicolumn{2}{|c|}{ Total } & \\
\hline & $\mathbf{n}$ & $\%$ & $\mathbf{n}$ & $\%$ & $\mathbf{n}$ & $\%$ & \\
\hline Sedang & 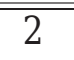 & $\overline{18,2}$ & 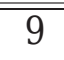 & 81,8 & 11 & 100 & \\
\hline Berat & 12 & 54,5 & 10 & 45,5 & 22 & 100 & 0,51 \\
\hline Total & 14 & 42,4 & 19 & 57,6 & 33 & 100 & \\
\hline
\end{tabular}

Sumber: Data primer 2018

Tabel 11. Analisis pengaruh durasi olahraga terhadap kadar hormone LH

\begin{tabular}{cccccccc}
\hline \hline \multirow{2}{*}{$\begin{array}{c}\text { Durasi } \\
\text { Olahraga }\end{array}$} & \multicolumn{6}{c}{ Normal } & \multicolumn{2}{c}{ Rendah } & \multicolumn{2}{c}{ Total } & \multirow{2}{*}{ P } \\
\cline { 2 - 7 } & $\mathbf{n}$ & $\mathbf{\%}$ & $\mathbf{n}$ & $\mathbf{\%}$ & $\mathbf{n}$ & $\mathbf{\%}$ & \\
\hline \hline Sedang & 7 & 46,7 & 8 & 53,3 & 15 & 100 & \multirow{2}{*}{0,65} \\
Berat & 7 & 38,9 & 11 & 61,1 & 18 & 100 & \\
\hline Total & $\mathbf{1 4}$ & $\mathbf{4 2 , 4}$ & $\mathbf{1 9}$ & $\mathbf{5 7 , 6}$ & $\mathbf{3 3}$ & $\mathbf{1 0 0}$ & \\
\hline \hline
\end{tabular}

Sumber: Data primer 2018

Tabel 12. Analisis pengaruh frekuensi olahraga terhadap kadar hormone LH

\begin{tabular}{cccccccc}
\hline \hline \multirow{2}{*}{$\begin{array}{c}\text { Frekuensi } \\
\text { Olahraga }\end{array}$} & \multicolumn{6}{c}{ Normal } & \multicolumn{2}{c}{ Rendah } & \multicolumn{2}{c}{ Total } & \multirow{2}{*}{ P } \\
\cline { 2 - 7 } & $\mathbf{n}$ & $\mathbf{\%}$ & $\mathbf{n}$ & $\mathbf{\%}$ & $\mathbf{n}$ & $\mathbf{\%}$ & \\
\hline \hline Rutin & 1 & 20,0 & 4 & 80,0 & 5 & 100 & \multirow{2}{*}{0,36} \\
Sangat Rutin & 13 & 46,4 & 15 & 53,6 & 28 & 100 & \\
\hline Total & $\mathbf{1 4}$ & $\mathbf{4 2 , 4}$ & $\mathbf{1 9}$ & $\mathbf{5 7 , 6}$ & $\mathbf{3 3}$ & $\mathbf{1 0 0}$ & \\
\hline \hline
\end{tabular}

Sumber: Data primer 2018

Tabel 13. Analisis pengaruh jenis olahraga terhadap siklus haid

\begin{tabular}{|c|c|c|c|c|c|c|c|c|c|}
\hline \multirow{3}{*}{ Jenis Olahraga } & \multicolumn{8}{|c|}{ Siklus Haid } & \multirow{3}{*}{$\mathbf{P}$} \\
\hline & \multicolumn{2}{|c|}{ Amenorea } & \multicolumn{2}{|c|}{ Oligomenorea } & \multicolumn{2}{|c|}{ Polimenorea } & \multicolumn{2}{|c|}{ Total } & \\
\hline & $\mathbf{n}$ & $\%$ & $\mathbf{n}$ & $\%$ & $\mathbf{n}$ & $\%$ & $\mathbf{n}$ & $\%$ & \\
\hline Sedang & 3 & 27,3 & 1 & 9,1 & 7 & 63,6 & 11 & 100 & \\
\hline Berat & 4 & 18,2 & 11 & 50,0 & 7 & 31,8 & 22 & 100 & 0,046 \\
\hline Total & 7 & 21,2 & 12 & 36,4 & 14 & 42,4 & 33 & 100 & \\
\hline
\end{tabular}

Sumber: Data primer 2018

Tabel 14. Analisis pengaruh durasi olahraga terhadap siklus haid

\begin{tabular}{|c|c|c|c|c|c|c|c|c|c|}
\hline \multirow{3}{*}{ Durasi Olahraga } & \multicolumn{8}{|c|}{$\begin{array}{l}\text { Siklus Haid } \\
\end{array}$} & \multirow{3}{*}{$\mathbf{P}$} \\
\hline & \multicolumn{2}{|c|}{ Amenorea } & \multicolumn{2}{|c|}{ Oligomenorea } & \multicolumn{2}{|c|}{ Polimenorea } & \multicolumn{2}{|c|}{ Total } & \\
\hline & $\mathbf{n}$ & $\%$ & $\mathbf{n}$ & $\%$ & $\mathbf{n}$ & $\%$ & $\mathbf{n}$ & $\%$ & \\
\hline Sedang & 0 & 0 & 5 & 33,3 & 10 & 66,7 & 15 & 100 & \\
\hline Berat & 7 & 38,9 & 7 & 38,9 & 4 & 22,2 & 18 & 100 & 0,002 \\
\hline Total & 7 & 21,2 & 12 & 36,4 & 14 & 42,4 & 33 & 100 & \\
\hline
\end{tabular}

Sumber: Data primer 2018 
Tabel 15. Analisis pengaruh frekuensi olahraga terhadap siklus haid

\begin{tabular}{cccccccccc}
\hline \hline \multirow{2}{*}{$\begin{array}{c}\text { Frekuensi } \\
\text { Olahraga }\end{array}$} & \multicolumn{1}{c}{ Amenorea } & \multicolumn{9}{c}{ Oligomenorea } & Polimenorea & \multicolumn{2}{c}{ Total } & \multirow{2}{*}{ P } \\
\cline { 2 - 9 } & $\mathbf{n}$ & $\mathbf{\%}$ & $\mathbf{n}$ & $\mathbf{\%}$ & $\mathbf{n}$ & $\mathbf{\%}$ & $\mathbf{n}$ & $\mathbf{\%}$ & \\
\hline \hline Rutin & 0 & 0 & 0 & 0 & 5 & 100 & 5 & 100 & \multirow{2}{*}{007} \\
Sangat Rutin & 7 & 25,0 & 12 & 42,9 & 9 & 32,1 & 22 & 100 & \\
\hline Total & $\mathbf{7}$ & $\mathbf{2 1 , 2}$ & $\mathbf{1 2}$ & $\mathbf{3 6 , 4}$ & $\mathbf{1 4}$ & $\mathbf{4 2 , 4}$ & $\mathbf{3 3}$ & $\mathbf{1 0 0}$ & \\
\hline \hline
\end{tabular}

Sumber: Data primer 2018

Tabel 16. Analisis pengaruh frekuensi olahraga terhadap siklus haid

\begin{tabular}{|c|c|c|c|c|c|c|c|c|c|}
\hline \multirow{3}{*}{ Hormon FSH } & \multicolumn{8}{|c|}{ Siklus Haid } & \multirow{3}{*}{$\mathbf{P}$} \\
\hline & \multicolumn{2}{|c|}{ Amenorea } & \multicolumn{2}{|c|}{ Oligomenorea } & \multicolumn{2}{|c|}{ Polimenorea } & \multicolumn{2}{|c|}{ Total } & \\
\hline & $\mathbf{n}$ & $\%$ & $\mathbf{n}$ & $\%$ & $\mathbf{n}$ & $\%$ & $\mathbf{n}$ & $\%$ & \\
\hline Rendah & $\overline{77}$ & $\overline{33,3}$ & 12 & 57,1 & 2 & 9,5 & $\overline{21}$ & 100 & \\
\hline Normal & 0 & 0 & 0 & 0 & 12 & 100 & 12 & 100 & 0,000 \\
\hline Total & 7 & 21,2 & 12 & 36,4 & 14 & 42,4 & 33 & 100 & \\
\hline
\end{tabular}

Sumber: Data primer 2018

Tabel 17. Analisis pengaruh kadar hormone LH terhadap siklus haid

\begin{tabular}{|c|c|c|c|c|c|c|c|c|c|}
\hline \multirow{3}{*}{ Hormon LH } & \multicolumn{8}{|c|}{ Siklus Haid } & \multirow{3}{*}{$\mathbf{P}$} \\
\hline & \multicolumn{2}{|c|}{ Amenorea } & \multicolumn{2}{|c|}{ Oligomenorea } & \multicolumn{2}{|c|}{ Polimenorea } & \multicolumn{2}{|c|}{ Total } & \\
\hline & $\mathbf{n}$ & $\%$ & $\mathbf{n}$ & $\%$ & $\mathbf{n}$ & $\%$ & $\mathbf{n}$ & $\%$ & \\
\hline Rendah & 7 & 36,8 & 1 & 5,3 & 11 & 57,9 & 19 & 100 & \\
\hline Normal & 0 & 0 & 11 & 78,6 & 3 & 21,4 & 14 & 100 & 0,000 \\
\hline Total & 7 & 21,2 & 12 & 36,4 & 14 & 42,4 & 33 & 100 & \\
\hline
\end{tabular}

Sumber: Data primer 2018

Tabel 18. Analisis pengaruh Intensitas olahraga (jenis, durasi dan frekuensi) terhadap Hormon FSH

\begin{tabular}{|c|c|c|c|c|c|c|c|}
\hline \multirow{3}{*}{ Model } & \multicolumn{5}{|c|}{ Coefficients $^{a}$} & & \\
\hline & \multicolumn{2}{|c|}{$\begin{array}{l}\text { Unstandardized } \\
\text { Coefficients }\end{array}$} & \multirow{2}{*}{$\begin{array}{c}\begin{array}{c}\text { Standardized } \\
\text { Coefficients }\end{array} \\
\text { Rots }\end{array}$} & \multirow{2}{*}{$\mathbf{t}$} & \multirow{2}{*}{ Sig. } & \multicolumn{2}{|c|}{$\begin{array}{l}\text { 95,o\% Confidence } \\
\text { Interval for B }\end{array}$} \\
\hline & $\mathbf{R}$ & $\begin{array}{l}\text { Std. } \\
\text { Error }\end{array}$ & & & & $\begin{array}{c}\text { Lower } \\
\text { Bound }\end{array}$ & $\begin{array}{l}\text { Upper } \\
\text { Bound }\end{array}$ \\
\hline (Constant) & ,333 & (300 & & 1,110 & 276 &,- 281 & ,947 \\
\hline Jenis Olah Raga & $-7.61 E-13$ & 206 & 000 &, 000 & 1,000 &,- 420 & 420 \\
\hline Durasi Latihan & ,233 & 176 & 242 & 1,326 & ,195 &,- 127 &, 593 \\
\hline Frekuensi Latihan & ,600 & ,305 & , 447 & 1,968 & ,059 &,- 023 & 1,223 \\
\hline (Constant) & ,333 & 263 & & 1,269 & ,214 &,- 203 & 870 \\
\hline Durasi Latihan & 233 & 159 & ,242 & 1,464 & 154 &,- 092 &, 559 \\
\hline Frekuensi Latihan & 600 & 221 & ,447 & 2,711 & 011 & ,148 & 1,052 \\
\hline (Constant) &, 500 & 241 & & 2,075 & 046 & 009 & ,991 \\
\hline Frekuensi Latihan &, 750 & 200 &, 559 & 3,754 &, 001 & ,343 & 1,157 \\
\hline
\end{tabular}

a. Dependent Variable: HORMON_FSH

Sumber: Data primer 2018 
Tabel 19. Analisis pengaruh durasi olahraga terhadap siklus haid

\begin{tabular}{|c|c|c|c|c|c|c|c|}
\hline \multirow{3}{*}{ Model } & \multicolumn{5}{|c|}{ Coefficients $^{\mathbf{a}}$} & & \\
\hline & \multicolumn{2}{|c|}{$\begin{array}{c}\text { Unstandardized } \\
\text { Coefficients }\end{array}$} & \multirow{2}{*}{$\begin{array}{c}\begin{array}{c}\text { Standardized } \\
\text { Coefficients }\end{array} \\
\text { Roto }\end{array}$} & \multirow{2}{*}{$\mathbf{t}$} & \multirow{2}{*}{ Sig. } & \multicolumn{2}{|c|}{$\begin{array}{c}\text { 95,0\% Confidence } \\
\text { Interval for B }\end{array}$} \\
\hline & $\mathbf{R}$ & $\begin{array}{l}\text { Std. } \\
\text { Error }\end{array}$ & & & & $\begin{array}{l}\text { Lower } \\
\text { Bound }\end{array}$ & $\begin{array}{l}\text { Upper } \\
\text { Bound }\end{array}$ \\
\hline (Constant) & ,667 & 489 & & 1,363 & , 183 &,- 333 & 1,667 \\
\hline Jenis Olah Raga & 5.16E-14 & ,335 & ,000 & ,000 & 1,000 & -685 & ,685 \\
\hline Durasi Latihan & ,667 & 287 & ,432 & 2,325 &, 027 & ,080 & 1,253 \\
\hline Frekuensi Latihan &, 500 & ,497 & ,233 & 1,007 & , 322 &,- 516 & 1,516 \\
\hline (Constant) & ,667 & ,428 & & 1,559 & , 130 &,- 207 & 1,540 \\
\hline Durasi Latihan & ,667 & 260 & ,432 & 2,568 & 015 & ,136 & 1,197 \\
\hline Frekuensi Latihan &, 500 & ,361 & ,233 & 1,387 & , 176 &,- 236 & 1,236 \\
\hline (Constant) & 1,000 & ,359 & & 2,785 & 009 & 268 & 1,732 \\
\hline Frekuensi Latihan & ,833 & ,234 &, 540 & 3,568 & 001 & ,357 & 1,310 \\
\hline
\end{tabular}

a. Dependent Variable: SIKLUS_HAID

Sumber: Data primer 2018

Tabel 20. Analisis pengaruh Kadar hormone FSH terhadap siklus haid

\begin{tabular}{|c|c|c|c|c|c|c|c|}
\hline \multirow{3}{*}{ Model } & \multicolumn{5}{|c|}{ Coefficients $^{\mathbf{a}}$} & & \\
\hline & \multicolumn{2}{|c|}{$\begin{array}{c}\text { Unstandardized } \\
\text { Coefficients }\end{array}$} & \multirow{2}{*}{$\begin{array}{c}\begin{array}{c}\text { Standardized } \\
\text { Coefficients }\end{array} \\
\text { Roto }\end{array}$} & \multirow{2}{*}{$\mathbf{t}$} & \multirow{2}{*}{ Sig. } & \multicolumn{2}{|c|}{$\begin{array}{l}95,0 \% \text { Confidence } \\
\text { Interval for B }\end{array}$} \\
\hline & $\mathbf{R}$ & $\begin{array}{l}\text { Std. } \\
\text { Error }\end{array}$ & & & & $\begin{array}{l}\text { Lower } \\
\text { Bound }\end{array}$ & $\begin{array}{l}\text { Upper } \\
\text { Bound } \\
\end{array}$ \\
\hline (Constant) & $-1,347$ & ,347 & & $-3,885$ & 001 & $-2,055$ &,- 639 \\
\hline FSH & 1,703 & , 142 & 1,065 & 11,954 & ,000 & 1,412 & 1,994 \\
\hline $\mathrm{LH}$ &, 868 & ,139 &, 558 & 6,260 &, 000 &, 585 & 1,151 \\
\hline
\end{tabular}

a. Dependent Variable: SIKLUS_HAID

Sumber: Data primer 2018

\section{HASIL PENELITIAN}

Hubungan intensitas olah raga (jenis, durasi dan frekuensi) terhadap kadar hormone FSH dan LH.

Berdasarkan hasil penelitian jenis, durasi dan frekuensi olahraga terhadap kadar hormone LH atlet wanita, maka hasil yang didapatkan pada jenis olahraga berat didapatkan kadar hormone LH normal sebesar 12 orang $(54,4 \%)$ dan kadar hormone LH yang menurun sebesar 10 orang (45,5\%). Untuk Jenis olahraga sedang ada 9 orang $(81,8 \%)$ yang mengalami penurunan kadar $\mathrm{LH}$ sedangkan 2 orang $(18,2 \%)$ kadar hormone LH normal. Pada durasi olahraga didapatkan durasi latihan yang berat mengalami penurunan kadar hormone LH sebanyak 11 orang $(61,1 \%)$ dan sebesar 7 orang $(38,9 \%)$ kadar hormone LH normal. Sedangkan untuk durasi olahraga sedang kadar hormone LH normal sebanyak 7 orang $(46,7 \%)$ dan 8 orang $(53,3 \%)$ mengalami penurunan. Kemudian untuk frekuensi olahraga yang berat terdapat 15 orang $(53,6 \%)$ mengalami penurunan kadar hormone LH dan 13 orang $(46,4 \%)$ kadar hormone LH normal. Sedangkan frekuensi olahraga sedang 4 orang (80\%) yang mengalami penurunan kadar hormone LH, dan 1 orang (20\%) kadar hormone LH normal. 
Darihasil penelitian diatas, dapatterlihat bahwa pada intensitas olah raga berupa jenis, durasi dan frekuensi pada olahraga berat yaitu termasuk didalam penelitian ini adalah olahraga pencak silat, karate, taekwondo dan tinju mengalami penurunan kadar hormone FSH dan LH. Penggunaan energi yang tidak seimbang dapat menyebabkan penurunan pulsatile Gonadotropin Releasing Hormone (GNRH) dalam hal ini FSH dan LH sesuai dengan penelitian Quah tahun 2009 pada atlet non-leannes sport di Malaysia yang ratarata kadar hormone FSH dan LH menurun.

Hal ini juga sesuai dengan penelitian Carbon dan Saadiah 2014 yaitu atlet akan mengalami gangguan sikus haid yang akan berpengaruh pada mekanisme hipotesis yang mana latihan akan mempengaruhi siklus menstruasi dengan melibatkan hipotalamushipofisis-aksis adrenal. Tujuan pemeriksaan FSH dan LH adalah untuk melihat fungsi sekresi hormon yang dikeluarkan oleh hipotalamus dan mekanisme fisiologis umpan balik dari organ target yaitu testis dan ovarium. Kadar FSH akan meningkat pada hipogonadism, pubertas prekoks, menopause, kegagalan diferensiasi testis, orchitis, seminoma, acromegall, sidroma Turner. Serta menurun pada keadaan insufisiensi hipotalamus, disfungsi gonad, anovulasi, insufisiensi hipofise, dan tumor ovanium. Faktor yang mempengaruhi kadarnya adalah obat-obatan seperti steroid, kontrasepsi oral, progesteron, estrogen, dan testoteron

Berdasarkan analisis multivariate menunjukkan bahwa variable yang paling berpengaruh terhadap hormone FSH adalah frekuensi olahraga dengan nilai signifikan adalah 0,001 setelah dikontrol oleh variable jenis olahraga dan durasi olahraga. sehingga dapat ditafsirkan bahwa variable frekuensi olahraga memiliki pengaruh terhadap kadar hormone FSH.

Hubungan antara meningkatnya frekuensi olahraga pada pelari dengan gangguan menstruasi telah banyak ditemukan dalam penelitian, termasuk hubungan yang hampir linear dengan kejadian amenorea dikarenakan adanya gangguan hormonal. Perubahan hormon yang ditemui pada wanita dengan aktivitas tinggi mencakup penurunan hebat kadar FSH, peningkatan kadar LH, penurunan progesteron selama fase luteal, penurunan kadar estrogen pada fase folikular, dan lingkungan FSH-LH yang sama sekali tidak seimbang dibandingkan dengan wanita yang tidak beraktivitas tinggi seusianya (Carbon,R.J,2014)

Hal ini sesuai dengan penelitian RichEdwards dalam Sianipar (2009) menyebutkan bahwa pada wanita Amerika, peningkatan aktivitas fisik terutama pada frekuensi justru berhubungan dengan risiko berkurangnya kejadian ovulasi. Ovulasi tidak terjadi apabila kadar hormone FSH mengalami penurunan dikarenakan fase folikuler memendek akibat dari penambahan frekuensi aktivitas fisik intensitas berat per minggu terkait dengan penurunan $7 \%$ risiko terjadinya masalah ovulasi.

\section{Hubungan intensitas olah raga (jenis, durasi dan frekuensi) terhadap kadar Siklus haid.}

Berdasarkanhasilpenelitianjenis, durasi dan frekuensi olahraga terhadap kadar siklus haid atlet wanita, maka hasil yang didapatkan pada jenis olahraga berat didapatkan siklus haid terbanyak Oligomenorea sebanyak 11 orang $(50,0 \%)$, Polimenorea 7 orang $(31,8 \%)$ 
dan amenorea 4 orang $(18,2 \%)$. Sedangkan untuk jenis olahraga sedang terdapat 7 orang $(63,6 \%)$ Polimenorea, ada 3 orang $(27,3 \%)$ amenorea dan 1 orang $(91,1 \%)$ Oligomenorea. Untuk durasi olahraga berat siklus haid yang terbanyak yaitu Amenorea dan oligomenorea sebanyak 7 orang $(38,9 \%)$ dan siklus haid Polimenorea sebanyak 4 orang $(22,2 \%)$. Sedangkan untuk durasi olahraga sedang terdapat 10 orang $(66,7 \%)$ mengalami Polimenorea, 5 orang $(33,3 \%)$ Oligomenorea dan tidak ada yang mengalami amenorea. Untuk frekuensi olahraga berat sebanyak 12 orang $(42,9 \%)$ mengalami Oligomenorea, 9 orang $(32,1 \%)$ Polimenorea dan 7 orang (25\%) mengalami Amenorea. Sedangkan untuk frekuensi olahraga sedang hanya terdapat atlet yang mengalami Polimenorea sebanyak 5 orang (100\%).

Berdasarkan analisis multivariate menunjukkan bahwa variable yang paling berpengaruh terhadap siklus haid adalah durasi olahraga dengan nilai signifikan adalah 0,001 setelah dikontrol oleh variable jenis olahraga dan frekuensi olahraga. sehingga dapat ditafsirkan bahwa variable durasi olahraga memiliki pengaruh terhadap siklus haid.

Hasil penelitian ini sejalan dengan penelitian yang dilakukan oleh Rima Asmarani (2010) yang mengatakan adanya hubungan jenis, durasi dan frekuensi latihan terhadap siklus menstruasi. Sifat dan tingkat keparahan gejala siklus haid tergantung pada beberapa hal seperti jenis latihan, intensitas, dan lamanya latihan serta laju perkembangan program pelatihan. Aktivitas fisik berlebihan dapat menyebabkan terjadinya disfungsi hipotalamus yang menyebabkan gangguan pada sekresi GnRH. Haltersebut menyebabkan menarche yang tertunda dan gangguan siklus menstruasi dengan perubahan metabolism steroid yang mempengaruhi release atau penglepasan gonadotropin.

Menurut teori dari Anwar (2011) menstruasi dikatakan normal bila didapatkan siklus menstruasi tidak kurang dari 24 hari, tetapi tidak melebihi 35 hari. Dijelaskan dalam Anurogo dkk (2011) bahwa siklus menstruasi terdiri dari tiga fase, yaitu fase folikuler, fase ovulatoir, dan fase luteal. Dari hasil penelitian dapat dilihat sebagian atlet memiliki akitivitas fisik tingkat berat dan mengalami oligomenorrhea. Meningkatnya aktivitas fisik juga berhubungan positif dengan fase folikuler. Penelitian yang dilakukan di California menyebutkan wanita berusia kurang dari 35 tahun dengan aktivitas fisik $>4$ jam per minggu secara signifikan memperpanjang fase folikuler. Ketika aktivitas fisik kembali teratur maka fase folikuler juga akan sesuai dengan fase normalnya (Liu Y dkk, 2004).

Penelitian yang dilakukan oleh Patras UniversityMedical School juga menyatakan gangguan siklus menstruasi dan tertundanya menarche dialami oleh remaja dan wanita dewasa yang melakukan pelatihan secara intensif selama 15 jam atau lebih setiap minggunya (Nattiv A dkk, 2007). Intensitas aktivitas fisik yang terlalu tinggi sehingga tidak mampu dikompensasi oleh tubuh dapat menyebabkan gangguan endokrin dalam tubuh salah satunya ketidakteraturan siklus menstruasi (Jorge EC dkk, 2008). Rougier dan Linquette menemukan pengaruh yang bervariasi dari olahraga terhadap siklus menstruasi pada mahasiswa olahraga, demikian juga Kabisch yang mengevaluasi atletjerman, menemukan beberapa atlet yang 
mengalami amenorrhea. Juga Erderly yang meneliti atlit dunia dan Zhanel yang meneliti atlit anggar, menemukan 10-12\% kejadian disfungsi menstruasi (Hartono, 2003)

\section{Hubungan Kadar Hormon FSH dan LH terhadap kadar Siklus haid.}

Berdasarkan penelitian diatas, didapatkan kadar hormone FSH menurun sebanyak 12 orang $(57,1 \%)$ pada oligomenorea, dan 7 orang (33,3\%) amenorea dan 2 orang $(9,5 \%)$ polimenorea. Sedangkan untuk kadar hormone FSH normal sebanyak 12 orang $(100 \%)$ pada siklus polimenorea saja.

Untuk kadar hormone LH menurun didapatkan sebanyak 11 orang $(57,9 \%)$ dengan siklus polimenorea, 7 orang (36,8\%) amenorea dan 1 orang $(5,3 \%)$ oligomenorea. Sedangkan untuk kadar hormone LH normal didapatkan sebanyak 11 orang $(78,6 \%)$ pada siklus oligomenorea dan 3 orang $(21,4 \%)$ siklus polimenorea.

Berdasarkan analisis multivariate menunjukkan bahwa variable yang paling berpengaruh terhadap siklus haid adalah hormone FSH dengan nilai signifikan adalah 0,00 setelah dikontrol oleh variable hormone LH. Sehingga dapatditafsirkan bahwavariable kadar hormone FSH memiliki pengaruh terhadap siklus haid.

Berdasarkan hasil penelitian, didapatkan adanya penurunan FSH siklus haid berupa oligomenorea.Hal ini menunjukkan pula bahwa penggunaan energi yang tidak seimbang dapat menyebabkan penurunan pulsatile Gonadotropin Releasing Hormone (GNRH) dalam hal ini FSH dan LH sesuai dengan penelitian Quah tahun 2009 pada atlet non-leannes sport di Malaysia yang rata- rata kadar hormone FSH dan LH menurun. Penurunan pulsatile LH ini dengan kata lain tidak adanya lonjakan LH sehingga kadar LH didalam tubuh sangat rendah. Sehingga dapat mengakibatkan tidak terjadinya ovulasi yang mengakibatkan gangguan pola haid berupa amenorea maupun polimenorea. Penurunan kadar LH ini diakibatkan karena penggunaan energi yang tidak diimbangi dengan pemasukan energi yang adekuat sehingga menyebabkan hipoestrogen dan berakibat pada penurunan pulsatile GNRH. Dengan kata lain dari ketidakseimbangan penurunan pulsatile GNRH dalam hal ini FSH yang mengakibatkan terjadinya pemanjangan fase folikuler.

Untuk siklus polimenorea menurut penelitian Patras UniversityMedical School disebabkan oleh karena adanya siklus anovulasi yang sering ditemukan pada siklus seksual saat pubertas. Siklus anovulasi ini terjadi karena lonjakan LH praovulasi yang tidak cukup besar sehingga ovulasi tidak berlangsung. Tidak adanya ovulasi menyebabkanperubahan yaitu corpus luteum yang gagal berkembang sehingga mengakibatkan tidak adanya sekresi progesterone selama bagian akhir dari siklus.

Menurut penelitian Aviz et al, 2014 diperkirakan bahwa $16 \%$ dari atlet wanita menderita gangguan menstruasi dari sumbu hipofisis, yaitu dari Gonadotropin Releasing Hormon (GnRh) yang akan berpengaruh pada FSH dan LH. Perubahan tingkat hormon yang disebabkan oleh aktivitas fisik terbukti menjadi alasan penting untuk penyimpangan dalam siklus menstruasi (Far et al., 2012). Tekanan mental dan fisik yang konstan menstimulasi sistem insentif pusat hipotalamus untuk melepaskan CRH Arginine 
dan Vasopressin yaitu neurotransmiter dan urine yang mengurangi hormon dan akhirnya melepaskan kortisol (Salehzadeh, 2015). Para peneliti percaya bahwa tekanan konstan yang diinduksi oleh latihan meningkatkan tingkat kortisol pada atlet wanita dan ini mengurangi dan bahkan mengganggu pelepasan gonadotropin dari hipotalamus.

\section{KESIMPULAN DAN SARAN Kesimpulan}

1. Ada hubungan antara intensitas olahraga (jenis, durasi dan frekuensi) terhadap siklus haid atlet.

2. Ada hubungan antara durasi dan frekuensi olahraga terhadap kadar hormone FSH namun tidak ada hubunganjenis olah raga terhadap kadar hormon FSH. Kemudian didapatkan pula tidak ada hubungan antara jenis,durasi dan frekuensi olahraga terhadap kadar hormone LHatlet.

3. Ada hubungan antara kadar hormone FSH dan LH dengan siklus haid atlet wanita di Pusat Pembinaan Latihan Pelajar.

4. Terdapat pengaruh frekuensi olahraga terhadap kadar hormone FSH pada atlet wanita di Pusat Pembinaan Latihan Pelajar.

5. Terdapat pengaruh durasi olahraga terhadap siklus haid pada atlet wanita di PusatPembinaan Latihan Pelajar.

6. Terdapat pengaruh kadar hormone FSH terhadap siklus haid pada atlet wanita di PusatPembinaan Latihan Pelajar.

\section{Saran}

1. Hendaknya pelatih memberikan durasi dan frekuensi latihan yang optimal dengan memperhitungkan kecukupan nutrisi yang seimbang bagi para atlet sesuai saran dari ahli gizi.

2. Pelatih dan institusi olahraga perlu menyadari masalah kesehatan dalam hal inimengenai siklus haid pada atlit.

3. Untuk dilakukan edukasi kepada para atlet wanita mengenai pentingnya kesehatan reproduksi terutama tentang siklus menstruasi yang teratur.

\section{DAFTAR PUSTAKA}

1. Ahrens, K.A., Vladutiu, C. J., Mumford, S. L., Schliep, K. C., Perkins, N. J., WactawskiWende, J. \& Schisterman, E. F. 2014. The effect of physical activity across the menstrual cycle on reproductive function. Annals of epidemiology, 24, 127-134.

2. Ainsworth, B. E. \& Macera, C. A. 2018. Promoting physical activity in a public health context. Journal of Sport and Health Science, 7, 1-2.

3. Anwar, M., Baziad, A. \& Probowo, R. 2011. Ilmu Kandungan, Jakarta, Bina Pustaka Sarwono Prawirohardjo.

4. Aviz, R. Z., Rezayian, T. F. \& Somayeh 2014. The Effects of Endurance Running Training on Luteal Phase Disorders in Elite Female Athletes. Sports and Kinetic Journal 3.

5. Aron,D.C and Findling,J.W. Hipotalamus \& pituitary. In Francis S.G and Gordon. Basic and Clinical Endocrinology. $5^{\text {th }}$ Edition.2007.Prentice HallInternational Inc. 
6. Bae, J., Park, S. \& Kwon, J.-W. 2018. Factors associated with menstrual cycle irregularity and menopause. $B M C$ Women's Health, 18, 36.

7. Berga, S. \& Naftolin, F. 2012. Neuroendocrine control of ovulation. GynecolEndocrinol, 28 Suppl 1,9-13.

8. Bjelobaba, I., Stojilkovic, S. S. \& Naor, Z. 2018. Editorial:Gonadotropin-Releasing Hormone Receptor Signaling and Functions. Frontiersin Endocrinology, 9.

9. Booth, F.W., Roberts, C. K. \& Laye, M.J. 2012. Lack of exercise is a major cause of chronic diseases. Comprehensive Physiology, 2, 1143-1211.

10. Brar, T.K., Singh, K. D. \& Kumar, A. 2015. Effect of Different Phases of Menstrual Cycle on Heart Rate Variability (HRV). Journal of Clinical and Diagnostic Research: JCDR, 9, CC01-CC04.

11. Braunstein,GD. testes. in Francis S.G, Basic and Clinical Endocrinology, \%th Edition, 2007, London: Prentice-Hall International Inc.

12. Carter, S. 2018. Female Athlete Triad (Triad) / Relative Energy Deficiency in Sport (RED-S): A Perspective Interview with Professor Barbara Drinkwater. Int $J$ Sport Nutr Exerc Metab, 1-9.

13. Ciechanowska, M., Lapot, M., Mateusiak, J. \& Przekop, F. 2010. Neuroendocrine regulation of $\mathrm{GnRH}$ release and expression of $\mathrm{GnRH}$ and $\mathrm{GnRH}$ receptor genes in the hypothalamus-pituitary unit in different physiological states. Reprod Biol, 10, 85-124. 
